open 2 access

\title{
Brachial Plexus Injury: Recent Diagnosis and Management
}

Tito Sumarwoto ${ }^{1,2}$, Heri Suroto ${ }^{3}$, Ferdiansyah Mahyudin ${ }^{3}$, Dwikora Novembri Utomo ${ }^{3}$, Seti Aji Hadinoto $^{2}$, Muhammad Abdulhamid $^{2}$, Pamudji Utomo $^{2}$, Romaniyanto Romaniyanto ${ }^{2}$, R. Andhi Prijosedjati ${ }^{2}$, Sholahuddin Rhatomy ${ }^{4,5 *}$

${ }^{1}$ Doctoral Program, Faculty of Medicine, Airlangga University, Surabaya, Indonesia; ${ }^{2}$ Department of Orthopedics and Traumatology, Faculty of Medicine, Sebelas Maret University, Orthopedic Hospital Prof. Dr. R. Soeharso, Surakarta, Indonesia; ${ }^{3}$ Department of Orthopedics and Traumatology, Faculty of Medicine, Airlangga Universitym, Regional General Hospital Dr. Soetomo, Surabaya, Indonesia; ${ }^{4}$ Department of Orthopaedics and Traumatology, Dr. Soeradji Tirtonegoro General Hospital, Klaten, Indonesia; ${ }^{5}$ Faculty of Medicine, Public Health, and Nursing, Universitas Gadjah Mada, Yogyakarta, Indonesia

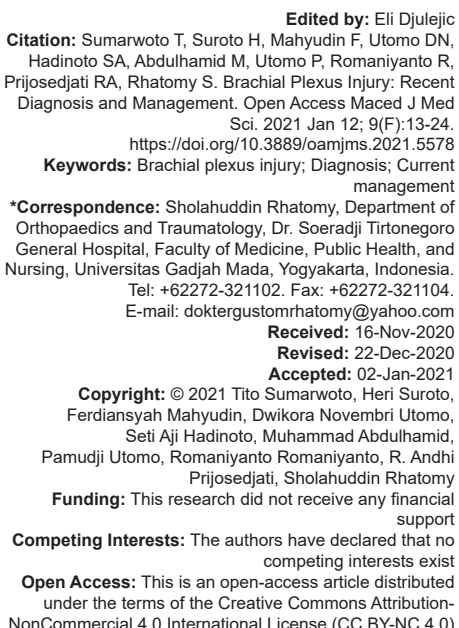

Edited by: Eli Djulejic Citation: Sumarwoto T, Suroto H, Mahyudin F, Utomo DN Hadinoto SA, Abdulhamid M, Utomo P, Romaniyanto R, Prijosedjati RA, Rhatomy S. Brachial Plexus Injury: Recen Diagnosis and Management. Open Access Maced J Med Sci. 2021 Jan 12; 9(F):13-24 https://doi.org/10.3889/oamjms.2021.5578 Keywords: Brachial plexus injury; Diagnosis; Current *Correspondence: Sholahuddin Rhatomy, Department Orthopaedics and Traumatology, Dr. Soeradii Tirtonent General Hospital, Faculty of Medicine, Public Health, and Nursing, Universitas Gadjah Mada Yogyakarta Tel: +62272-321102. Fax: +62272-321104 E-mail: doktergustomrhatomy@yahoo.com Received: 16-Nov-2020 Revised: 22-Dec-2020 Accepted: 02-Jan-202 Copyright: ๑ 2021 Tito Sumarwoto, Heri Suroto, Ferdiansyah Mahyudin, Dwikora Novembri Utomo, Pamudji Utomo, Romaniyanto Romaniyanto, R. Andhi Prijosedjati, Sholahuddin Rhatomy
Funding: This research did not receive any financia Competing Interests: The authors have declared that no competing interests exis Open Access: This is an open-access article distributed under the terms of the Creative Commons Attribution-

\section{Abstract}

Brachial plexus injury is known to be one of the most serious upper limb injuries, causes paralysis of the upper limbs and changes in activity of daily living, with the consequence disruption of activity of daily living, socio-economic problems, depression, and hopelessness. Management must be done properly. The evaluation and examination consist of detailed anamnesis on chronological events, complete physical examination, imaging studies, and electrophysiology study. Management can be done nonsurgically and surgically. Knowledge of the history of injury, timing of surgery, priority in restoring function, and managing patient expectations are important concepts in treating patient with brachial plexus injury. Timing is a very important thing. The results of these interventions vary depending on several parameters. Recognizing the basic principles of managing brachial plexus injuries is indispensable for all clinicians who treat these injuries.

\section{Introduction}

Brachial plexus injuries result from highenergy trauma to the neck and upper limbs [1], [2], [3]. Sudden movements can cause stress on the clavicle and adjacent structures including the brachial plexus and subclavian vasa. If the clavicle, the strongest link in the shoulder area is fractured, then all the tensile forces are transferred to the neurovascular fibers and nerve roots from the medulla which can lead to the upper limb muscle weakness innervated by $\mathrm{C} 5, \mathrm{C} 6, \mathrm{C} 7, \mathrm{C} 8$, and T1 nerve roots [4], [5], [6], [7], [8], [9], [10].

\section{Epidemiology}

The incidence and epidemiology show different rates in several countries. The incidence of peripheral nerve injury is 200,000/year and according to the United States Office of Rare Diseases, is more common in young men aged 15-25 years old. Research conducted in Central India in 2012 stated that road traffic accidents occurred in $94 \%$ of patients and $90 \%$ of the accidents were traffic accidents involving two-wheeled vehicles. In the United Kingdom, 450-500 cases of closed supraclavicular injury occur each year according to research conducted in 2012 [8], [9], [11].

\section{Anatomy}

The brachial plexus is a web of nerves originating from the spinal nerve innervates the superior limb. It consists of anterior nerve roots C5, C6, C7, C8, and T1. The $\mathrm{C} 5$ and $\mathrm{C} 6$ nerve roots unite to form upper trunk, $\mathrm{C} 7$ to form the middle trunk, and C8 and T1 to form lower trunk [8], [9], [12], [13], [14], [15], [16] [17] (Figure 1). 


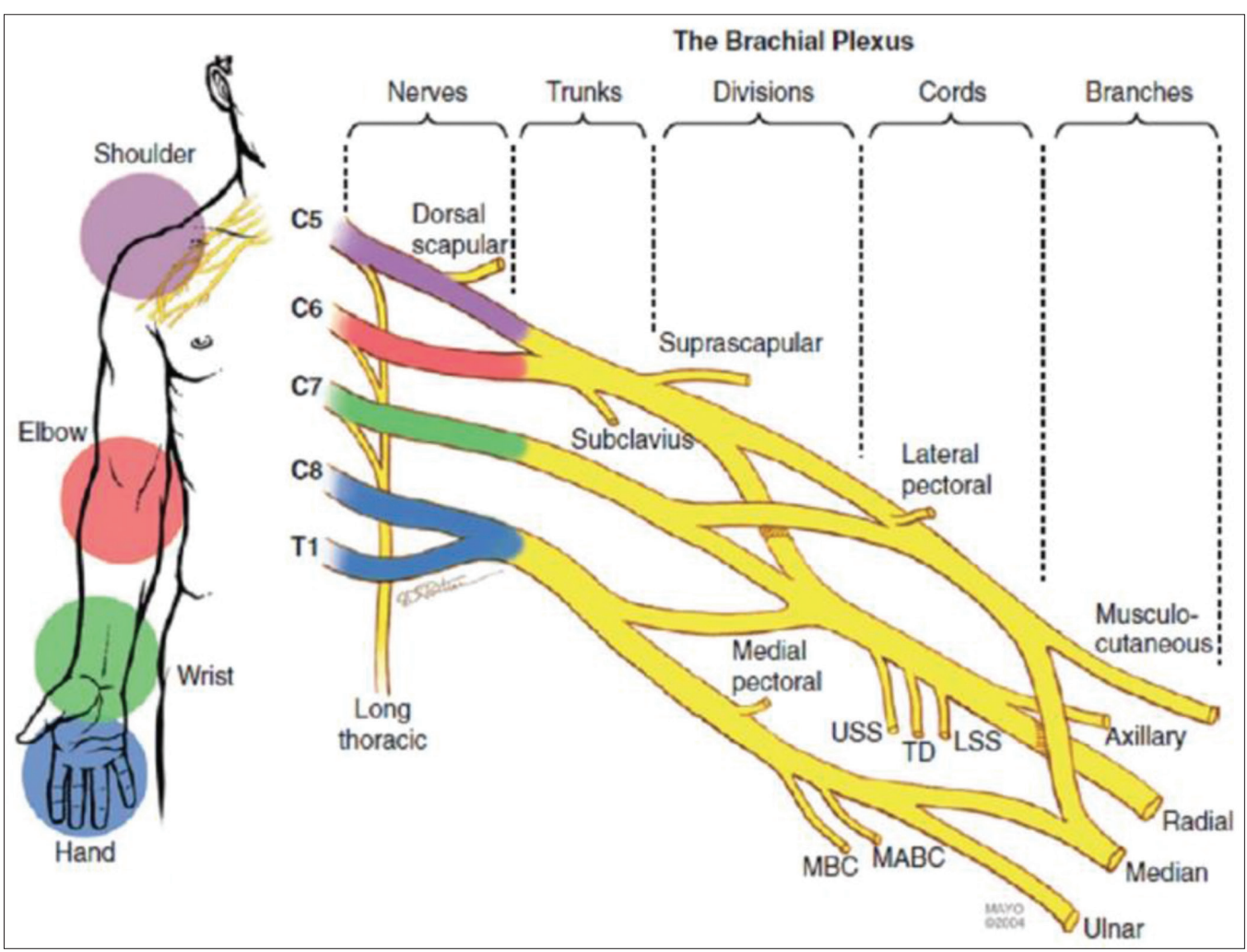

Figure 1: Anatomy of the brachial plexus [17]

An important nerve branch originating from the upper trunk is the suprascapular nerve. The trunks pass through the clavicle to form anterior and posterior divisions. The posterior divisions of the three trunks form the posterior fascicles. The lateral fascicles are formed from the anterior division of the upper trunk and medial trunk, while the anterior division of the inferior trunk becomes the medial fascicles. The posterior fascicles provide the radial nerve and the axillary nerve. The lateral fascicles give the musculocutaneous nerve. Other branches join the medial fascicles to form the median nerve. The medial fascicles provide the ulnar nerve and branches that form the median nerve [14], [18].

\section{Definition and Pathophysiology}

Brachial plexus injury causes paralysis of the upper limbs, usually on one side. Associated injury is followed in $54 \%$ cases, some of the accompanying injuries are bone fractures, vascular injuries, and head injuries [19], [20], [21], [22], [23].

Motorcycle accident is considered a high-energy impact trauma and can damage the brachial plexus if they occur in the upper extremities and the neck region. Usually, brachial plexus injury is associated with friction that distracts the upper arm and shoulder from the body or the neck. Sudden movements can cause friction of the clavicle and may as well affect the brachial plexus and subclavian vasa structures [8], [9], [24], [25], [26]. As in a motorcycle accident, the victim's head and neck hit the ground with his arms and head pulled in other direction. This injury causes hyper abduction of the shoulder and widening of the humeral angle of the scapula affecting the $\mathrm{C} 8$ and $\mathrm{T} 1$ nerve roots, preventing high-speed traction lead to avulsion of $\mathrm{C} 5, \mathrm{C} 6, \mathrm{C} 7, \mathrm{C} 8$, and T1. This mechanism refers primarily to nerve root avulsion lesions, occurs in $70-80 \%$ of the motorcycle accidents [27], [28] [29] (Figure 2).

The brachial plexus injury in newborn resulting from delivery is predominantly a traction injury. As in shoulder dystocia, the pulling of the baby's neck causes the angle between the shoulders and the neck to increase. Compression injuries are rare due to clavicle fractures, hematomas, and pseudo-aneurysms. Brachial plexus injuries can occur as a result of the force exerted by the delivery doctor in an attempt to resolve shoulder dystocia. Many reports of transient or persistent brachial plexus injury, including nerve root avulsions, occur both in vaginal delivery without shoulder dystocia and caesarean section [30], [31], [32] .

\section{Nerve Injury Classification}

Seddon described three types of nerve injury - neuropraxia, axonotmesis, and neurotmesis based on the severity of tissue injury, prognosis, and time to repair. Neuropraxia is the mildest type and is a 


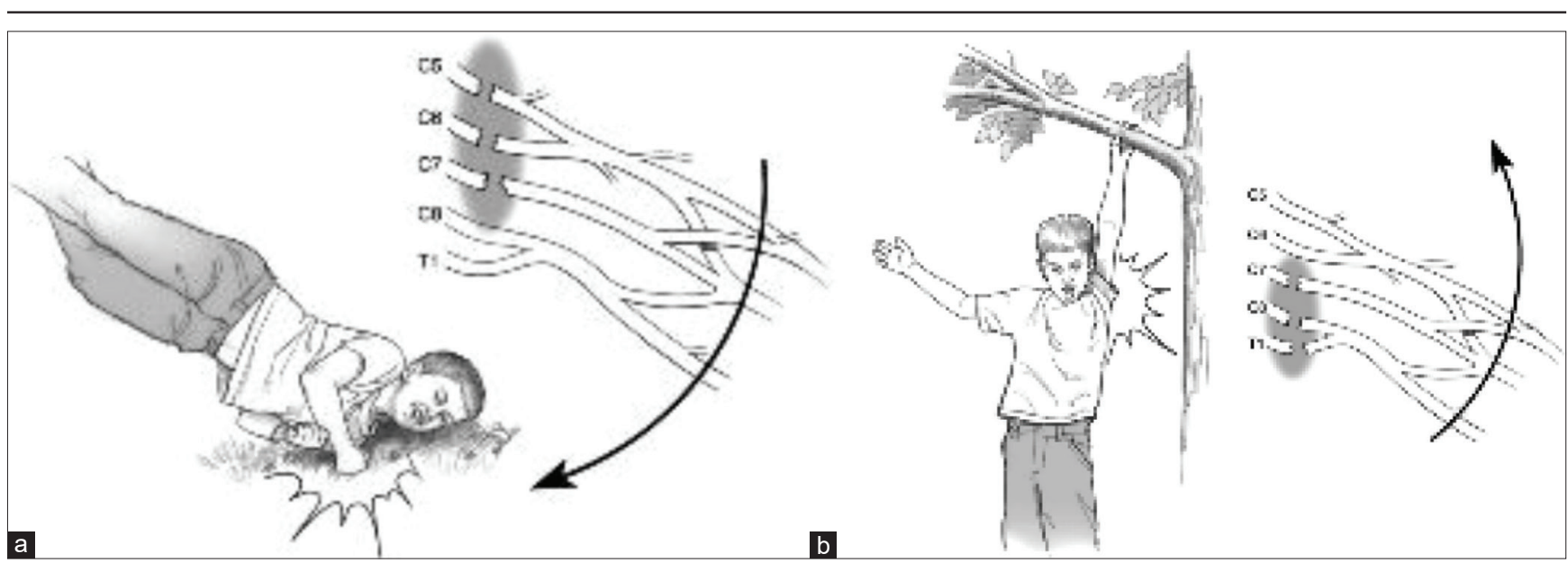

Figure 2: (a) The shoulder is pulled down while the head is forced to the opposite side, resulting in stretch, avulsion, or rupture of the upper nerve root (C5, C6, and C7), while the lower nerve roots are still normal (C8, T1); (b) with the shoulder experienced abduction and traction (hanging injury), the lower plexus (C8, and T1) may be injured [29]

form of inhibition of nerve impulse propagation without disruption of axons or perineurium. Axonotmesis refers to the loss of axonal continuity without the associated interference of fascicular connective tissue elements. Neurotmesis is the most severe type of injury, with impairment of the entire nerve and severe disturbance of the connective tissue component of the nerve with impaired sensory and motor recovery. In neurotmesis, the connective tissue skeleton is severely distorted or even lost [33], [34] [35] [36] (Table 1).

Table 1: Classification of nerve injury [36]

\begin{tabular}{lll}
\hline Sunderland [13] & Seddon [29] & Features \\
\hline Type 1 & Neuropraxia & Damage to local myelin only \\
Type 2 & Axonotmesis & Division of intraneural axons only \\
Type 3 & Axonotmesis & Division of axons and endoneurium \\
Type 4 & Axonotmesis & Division of axons, endo- and perineurium \\
Type 5 & Neurotmesis & Complete division of all elements including epineurium \\
Type 6* & Mixed & Combination of types 2-4 \\
\hline
\end{tabular}

Sunderland classifies nerve injury based on damage to the structure of nerves, from neuropraxia to neurotmesis, further stratified Seddon's three types of injury into five groups based on the severity of the injury. First degree injury is the same as neuropraxia according to Seddon's classification. Second, third, and fourth degree injuries are the same as axonotmesis, with different degrees of mesenchymal nerve damage. Fifth-grade injury equates to neurotmesis in the Seddon classification [32], [33], [37].

Brachial plexus injuries are classified into three groups: Preganglionic lesions, postganglionic lesions, and a combination. Preganglionic lesions indicate nerve root avulsion, and postganglionic lesions involve nerve structures distal to the dorsal root ganglion. This classification facilitates interpretation of clinical findings, provides guidelines for surgical decision-making, and information related to prognosis [38], [39].

Chuang has refined the classification method for various degrees of brachial plexus injury. The most common injuries are Level I injury [8], [9], [14], [40], [41], [42], [43], [44] (Table 2).
Table 2: Chuang's classification [14]

\begin{tabular}{|c|c|c|}
\hline $\begin{array}{l}\text { Chuang classification } \\
\text { level }\end{array}$ & Analogous to & Anatomic and surgical characteristics \\
\hline Level I & $\begin{array}{l}\text { Injury to the } \\
\text { preganglionic nerve } \\
\text { root (or supra } \\
\text { ganglionic) }\end{array}$ & $\begin{array}{l}\text { inside the bone (canal) } \\
\text { Requires a laminectomy to show nerve } \\
\text { roots }\end{array}$ \\
\hline Level II & $\begin{array}{l}\text { Postganglionic spinal } \\
\text { nerve injury }\end{array}$ & $\begin{array}{l}\text { Inside the scalenus muscle } \\
\text { Requires segmental muscle resection }\end{array}$ \\
\hline Level III & $\begin{array}{l}\text { Trunk and division } \\
\text { injuries }\end{array}$ & $\begin{array}{l}\text { Below clavicle } \\
\text { Requires osteotomy of the clavicle }\end{array}$ \\
\hline Level IV & $\begin{array}{l}\text { Injury to the fascicles } \\
\text { (chords) and terminal } \\
\text { branches }\end{array}$ & Infraclavicles \\
\hline
\end{tabular}

\section{Diagnostic Workup}

Brachial plexus trauma is clinically classified into Erb's Palsy/upper type (C5, C6, C7) and Klumpke's Palsy/lower type (C8, T1). In supraclavicular trauma, there will be adduction of the shoulder and internal rotation of the elbow in a pronated state. Injury to the suprascapular nerve located posterior to the suprascapular notch will provide a physical clinical picture of muscle weakness during shoulder abduction and external rotation of the upper arm. At the level of the spinoglenoid notch, it provides a clinical picture of weakness of the infraspinatus muscle. Trauma at the infraclavicular level can be caused by high-energy trauma to the shoulder and may be accompanied by axillary artery rupture. The axillary, suprascapular, and musculocutaneous nerves can be treated after trauma. Median, ulnar, and radial nerve assessment can be performed on finger and hand tests. Musculocutaneous and radial nerve lesions are characterized by weakness in flexion and extension of the elbow. Active abduction of the shoulder and stretching of the deltoid muscles will relieve the axillary nerve and suprascapular nerve [18], [42], [45], [46], [47] [49] (Table 3 and Figure 3). 
Table 3: Clinical features of brachial plexus injury

\begin{tabular}{|c|c|c|c|}
\hline $\begin{array}{l}\text { Affected branch } \\
\text { of the nerve } \\
\text { root }\end{array}$ & Paralyzed muscles & Loss of function & Sensory loss \\
\hline $\begin{array}{l}\text { C5 C6 (Erb's } \\
\text { palsy) }\end{array}$ & $\begin{array}{l}\text { Deltoid, supraspinatus, } \\
\text { infraspinatus, } \\
\text { subscapularis, major } \\
\text { pectoral, coracobrachialis, } \\
\text { biceps brachii, brachialis }\end{array}$ & $\begin{array}{l}\text { Shoulder } \\
\text { movement - } \\
\text { external rotation } \\
\text { of the upper arm, } \\
\text { flexion of the elbow }\end{array}$ & Thumb and index finger \\
\hline $\begin{array}{l}\text { C5 C6 C7 } \\
\text { (Erb's plus } \\
\text { palsy) }\end{array}$ & $\begin{array}{l}\text { All muscles above + } \\
\text { triceps brachii, serratus } \\
\text { anterior, wrist extensor } \\
\text { (ECRL-EDC), thumb } \\
\text { abduction-extension (APL, } \\
\text { EPL, and EPB) }\end{array}$ & $\begin{array}{l}\text { Shoulder } \\
\text { movements - } \\
\text { external rotation } \\
\text { of the upper arm, } \\
\text { elbow flexion, } \\
\text { winging scapula, } \\
\text { elbow extension, } \\
\text { wrist extension, } \\
\text { finger extension, } \\
\text { thumb abduction }\end{array}$ & $\begin{array}{l}\text { Thumb, index finger, } \\
\text { middle finger }\end{array}$ \\
\hline $\begin{array}{l}\text { C7 C8 Th1 } \\
\text { (Klumpke's } \\
\text { palsy) }\end{array}$ & $\begin{array}{l}\text { Latissimus dorsi, finger } \\
\text { flexor (FDS, FDP, and } \\
\text { FPL), finger extensors } \\
\text { (EDC, and EPL), intrinsic } \\
\text { hand muscles (lumbricals, } \\
\text { interossei, thenar, and } \\
\text { hypothenar) }\end{array}$ & $\begin{array}{l}\text { Flexion of the } \\
\text { thumb + fingers, } \\
\text { extension of the } \\
\text { fingers, function of } \\
\text { the median/ulnar } \\
\text { intrinsic muscles } \\
\text { of the hand }\end{array}$ & $\begin{array}{l}\text { Middle finger, ring finger } \\
\text { and little finger }\end{array}$ \\
\hline All roots & All muscles & All functions & All dorsal root nerves \\
\hline
\end{tabular}

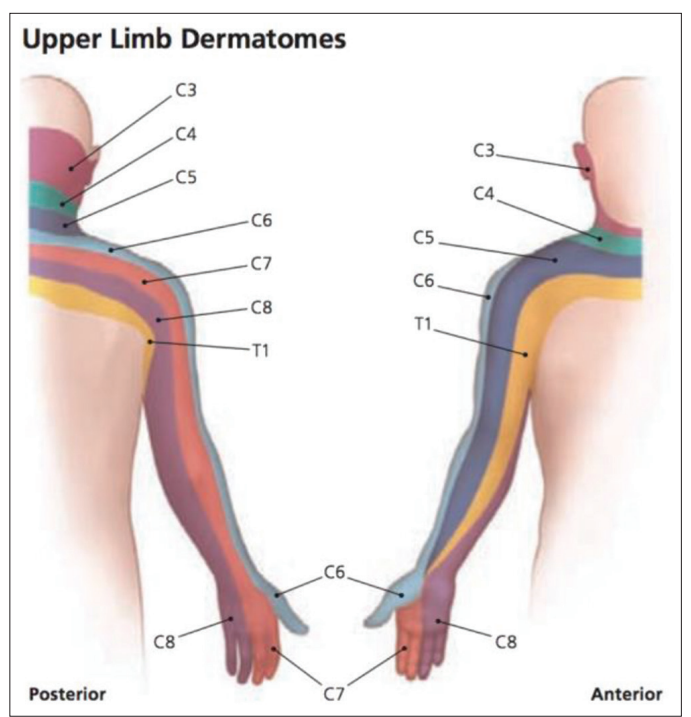

Figure 3: Brachial plexus' dermatome [48]

Evaluations consist of detailed anamnesis of the chronological events, complete physical examination including inspection of muscle atrophy, motoric examination, sensory examination, and evaluation of associated injury such as clavicle fractures, and evaluation regarding the possibility of Horner's syndrome (anhidrosis, ptosis, enophthalmos, and miosis) [49], [50], [51] (Figure 4).

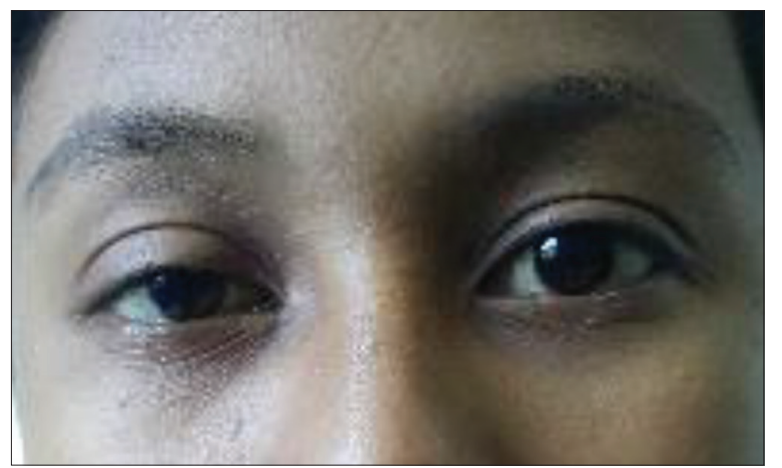

Figure 4: Ptosis of the right palpebra as a sign of Horner's Syndrome (author's property)
Clinical findings at baseline and subsequent examinations were recorded serially to determine if there was any improvement in function [49].

\section{Additional Examinations}

Imaging on brachial plexus injury is a plain chest radiograph, used to see the increase in the level of diaphragm (phrenic nerve injury) [52] (Figure 5).

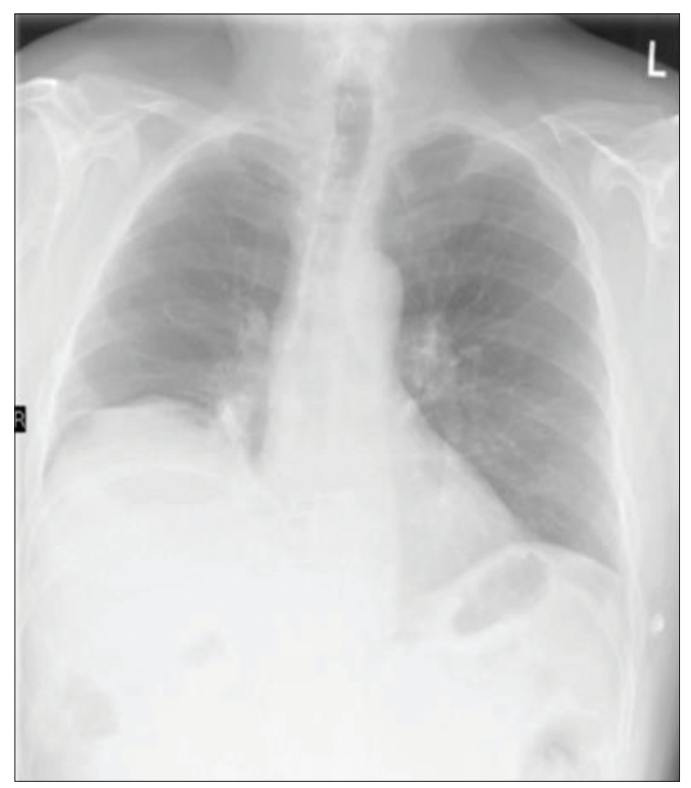

Figure 5: Elevation the right hemidiaphragm [52]

- CT myelography can show which nerve roots replaced in the brachial plexus injury, an asymmetrical or absence nerve root, or pseudomeningocele, strongly suggests nerve root avulsion [42], [49] (Figure 6).

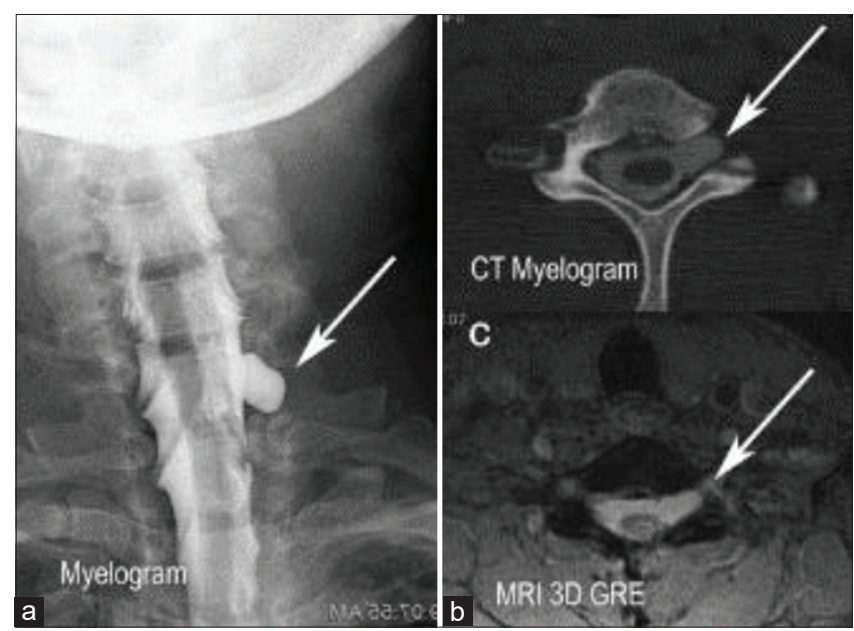

Figure 6: (a), (b) Pseudomeningocele cervical myelogram (white arrow). (c) Same pseudomeningocele in MRI cervical (white arrow) [49]

- Magnetic Resonance Imaging/MRI is noninvasive, clearly show the anatomy of the nerve roots [53], [54], [55]. 
Ultrasonography is $87 \%$ sensitivity, better accuracy at higher nerve root levels (C5-C7). Often difficult to visualize the distal nerve root due to the depth and amount of scar tissue that occurs after injury [49], [56].

- $\quad$ Magnetic Resonance Neurography (MRN) is the current gold standard for visualizing the brachial plexus [8], [9], [43], [44].

- Sensitive and specific for the identification of brachial plexopathy, provides detailed information the anatomy and pathology of the peripheral nerves, surrounding soft tissues and muscles, facilitating an accurate diagnosis [57].

- $\quad$ Electrophysiology study consists sensory and motor conduction, needle electromyography, action potential of somatosensory nerve, and intraoperative evaluation if indicated, done serially and evaluated collectively. Extensive sensory nerve conduction studies were performed to evaluate brachial plexus lesions [58], [59].

- An electrophysiology study can be done to assist the surgical intervention or other selected management [46].

\section{Initial Management}

\section{Open wound}

Open wounds are rare and range from small penetrating wounds to high-energy wounds. In acute nerve dissection, repair should be made quickly given the general clinical status of the patient. Thoracic injury and large vessel trauma often follow [8], [9], [42], [47].

If there is a delay, the scheduling of the second procedure must be carried out. An electromyographic examination may be performed to record the spontaneous potential with or without stimulation providing appropriate evidence for pre-operative planning 4-6 weeks after the injury. This period is the limit that allows for nerve to be repaired. A nerve graft is recommended rather than end-to-end anastomosis and nerve reconstruction [8], [9].

Open penetrating injuries such as low-energy gunshot wounds should not be explored directly. This injury almost always causes neuropraxia [1].

\section{Closed wound}

In the case of closed brachial plexus injuries and in the absence of other emergency injuries, surgical exploration, and recovery may not be carried out immediately. Recommendations include evaluation of the injury condition, pain management, and rehabilitation measures. If denervation continues, electromyography can be done after 3 or 4 weeks while CT/myelography or MRI after 6-8 weeks. In the absence of functional recovery or loss of neurological recovery, surgical intervention may be considered after 36 months. If clinical examination reveals a preganglionic lesion, and confirmed by imaging results, the necessary therapeutic strategy is nerve transfer [1].

\section{Conservative Management}

Conservative management is indicated if the diagnostic EMG shows that the damage is nondegenerative. The goals of conservative treatment are to maintain upper limb range of motion, maintain functional muscle, protect dermatome denervation, manage pain, and aid the healing process. Conservative management includes the use of assistive devices such as slings and splints to prevent uncontrolled positional movements of the paralyzed limb which can reduce the quality of life. Extensive physical therapy is also recommended as part of conservative management. $A$ passive range of movements can be used to maintain joint mobility and muscle strength in the arms. Electrical stimulation and therapeutic massage can also be done for edema and scar management [1], [2], [41], [60].

Significant pain occurred in incomplete brachial plexus injury at the root of the avulsion. Sufficient pain relief should be considered for each patient to minimize patient discomfort and maximize physiotherapeutic potential. NSAIDs and opioids can be helpful during initial therapy but do not help patients with neuropathy, who need antiepileptic drugs (gabapentin and carbamazepine) or antidepressants such as amitriptyline [1], [2], [40], [44], [61].

\section{Surgical Intervention}

Surgery is indicated if there is no substantial spontaneous recovery within 3 months and is necessary for exploration, or for further recovery. Complete paralysis as evidenced by the presence of pseudomeningoceles, and preganglionic avulsion is evident, surgical action should be carried out as soon as possible. All patients with lacerations near the brachial plexus should undergo exploration because in most of these injuries (sharp or blunt), there is no possibility of spontaneous repair. Surgical plans must be individualized and priorities must be established. Priorities are elbow flexion, stabilization, and abductionelevation-external rotation of the shoulder, elbow extension, wrist and finger extension, and wrist and finger flexion [62], [63]. 
Surgical management is divided into two categories: Primary procedures, surgery for nerve repair, and secondary procedures. If possible, surgery for nerve repair takes precedence over all other procedures because time becomes an important aspect. As soon as other injuries are treated, the patient should get nerve repair as early as possible. Secondary procedures are performed after the nerve repair whenever primary repair fails or it is done to augment primary repair, or in very late cases as a replacement for recovery function [2], [17].

\section{Primary procedures}

\section{Neurolysis}

Used to maintain continuity of nerve lesions and important for repairing the structure of nerves and nerve sheaths. The vascular weakness usually presence, so it is not recommended to use interfascicular neurolysis, because epineurectomy can be used to remove fibrous tissue. The use of nerve stimulation before and after neurolysis can be enhanced by nerve conduction. Many factors influence functional improvement and clinical outcome after neurolysis [1], [2], [8], [9], [40].

\section{Nerve graft}

The primary technique for severed nerve injuries, with a healthy proximal portion and no axial damage. Several things will affect the outcome of the procedure including the length of the nerve graft, the presence of scar tissue at the injury site, the number of grafts used, the presence of a healthy proximal part available for grafting, and the nerve gap. Postoperatively, the nerve must respond to somatosensory evoked potentials (SSEPs) and the conductivity of stimulated spinal nerve roots should be verified. This procedure is the basis of current surgical therapy for postganglionic spinal cord injury. When the damage is extensive, it is necessary to prioritize certain nerves for repair by grafting, especially those associated with elbow flexion, shoulder abduction, and forearm sensation [1], [2].

The sural nerve, the sensory branch of the ulnar nerve, and the medial antebrachial cutaneous nerve are the most commonly used nerve donors. The sural nerve can provide a neural tube up to $40 \mathrm{~cm}$. The donor site must remain there until the recipient site is ready. Immediately before the grafting procedure, the donor nerve must be inverted to minimize loss of the axial branch. In general, the use of nerve grafts shorter than $10 \mathrm{~cm}$ produces a better functional and clinical outcome compared to grafts longer [1], [45].

The use of free nerve grafts for peripheral functional recovery appears to be poor compared with reconstruction of the more proximal lesions. Another option is a vascular nerve graft if the ulnar nerve is used frequently. The ulnar nerve is divided into smaller grafts, the size of the sural nerve, thereby increasing the chances of success. Vascular nerve grafts do not appear to exceed free nerve grafts with respect to recovery and functional improvement. Surgical technique is an important factor for nerve graft results. The aim is always to achieve the best fixation without tension at the graft anastomosis point [1], [2], [45].

\section{Neurotization/nerve transfer}

Used for preganglionic nerve root injuries in brachial plexus injuries, transfers the neurofiber to an irreparable paralytic nerve. The motor branch is used as a donor to achieve motor reinnervation. Nerve transfer can be extraplexal or intraplexal. Intraplexal nerve transfer options include intact nerve roots. Other options include the use of the medial thoracic nerve and the ulnar nerve or inferior medial fascicles. Oberlin et al. described nerve transfer to the biceps muscle using a portion of the ulnar nerve for C5-C6 avulsion of the brachial plexus [1], [2].

Extraplexal nerve transfer options include the use of the intercostal nerve (ICN) and the spinal accessory nerve (N.XI). The phrenic nerves - accessed using an anterior neck approach - and the deep motor branches of the cervical plexus (C3-C4) can be used as donor nerves. In addition to the use of the deep motor branch of the cervical plexus, other donor nerves can restore elbow flexion and produce M3 bicep strength in about $75 \%$ of patients. The Oberlin technique is recommended for patients with upper nerve root avulsion and lower brachial plexus nerve root. Transfer of nerves to the biceps muscle using a portion of the ulnar nerve in upper type brachial plexus injury provides good functional and clinical results. The use of the Oberlin technique results in M3 or more biceps strength in $94-100 \%$ of patients and M4 biceps strength in $75-94 \%$ of the cases. This procedure requires the supply of the lower nerve root plexus. Oberlin I technique by re-innervating the biceps muscle using the ulnar nerve fascicle which is transferred to the motor branch of the musculocutaneous nerve to the biceps muscle (to restore elbow flexion), Oberlin II is Oberlin I augmented with the median nerve fascicle transferred to the motor branch of the musculocutaneous nerve to the brachial muscle [1], [2], [3], [64] (Figure 7).

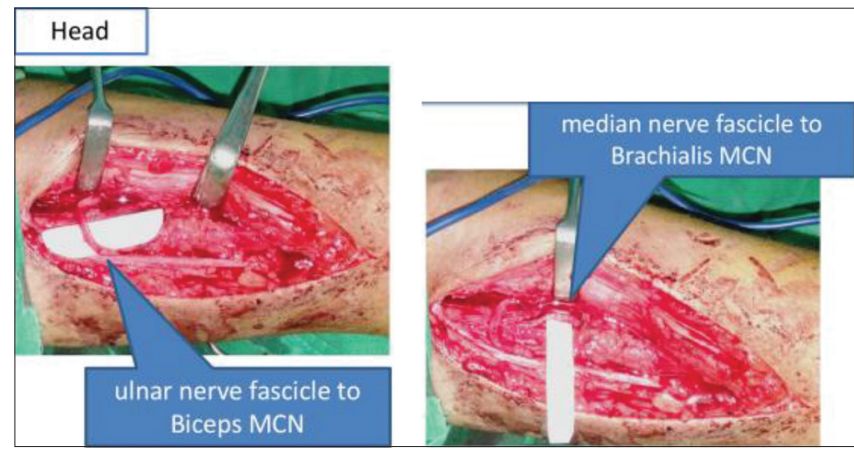

Figure 7: The Oberlin II technique (author's property) 
Another option is to use the spinal accessory nerve. These nerves are purely motor nerves but only the last one or two of them should be used to maintain normal function of the trapezius muscle. However, this nerve can be easily damaged in patients with pneumothorax, multiple rib fractures, or spinal cord trauma. The use of intercostal nerve transfers recorded no post-operative deficits. The phrenic nerve is a good donor nerve but should not forget about its contribution to respiratory function and the possibility of adverse effect, especially in patients with simultaneous intercostal nerve transfer. Gu et al. revealed no significant reduction in respiration after phrenic nerve transfer for motor neurotization of the brachial plexus [1], [2], [45].

Somsak technique for deltoid muscle is done by transferring the radial nerve which innervates the long head of the triceps to the posterior branch of the axillary nerve. The branches of the musculocutaneous nerve to the brachial muscle are given the median nerve to stretch the fingers [1], [2].

Contralateral C7 transfer is used for weakness as a whole or performed when other transfer options cannot be used. A graft is connected to the contralateral nerve root, which has been placed under the anterior scalenus muscle and longus colli muscle, and then passed through the retroesophageal space to deliver its signal to the receiving nerve, thus shortening the distance to the target nerve. The mean length of the nerve grafts used was 6.8 $\pm 1.9 \mathrm{~cm}$. The nerves that are often used as donors and recipients in this technique are shown in Table 4 [1], [2], [8], [40], [41], [43], [44], [65], [66], [67], [68].

Table 4: Types of nerve donors and recipients

\begin{tabular}{ll}
\hline Donor nerves & Recipient nerves \\
\hline Spinal accessory nerve (SAN) & Suprascapular Nerve (SSN) \\
& Musculocutaneous nerve \\
& Axillary Nerve \\
Intact Phrenic nerve or C5 nerve root & Suprascapular Nerve \\
& Musculocutaneous nerve \\
& Axillary Nerve \\
& Upper trunk \\
Inter Costal Nerve & Musculocutaneous nerve \\
& Long Thoracic Nerve \\
& Radial Nerve \\
& Median Nerve \\
& Ulnar nerve \\
Contralateral C7 nerve root & Median Nerve \\
& Musculocutaneous nerve \\
& Lateral Chords \\
Nerve of the biceps long head & Anterior branch of the axillary nerve \\
Hypoglossal nerve & Musculocutaneous nerve \\
& Lateral Chords \\
\hline
\end{tabular}

\section{Secondary procedures}

If there is no spontaneous improvement or when primary procedure surgery does not produce satisfactory results. There must be specific signs of neurological degradation or no possibility of neurological recovery, or sufficient time should pass without functional improvement. And for adult patients who initially presented late (more than 12 months after injury), primary nerve reconstruction procedures appear to have a much worse outcome, even in certain cases, distal nerve transfer can still be considered even after 12 months, but $<18$ months [64].

Arthrodesis, tenodesis, tendon, and muscular transfers, and functional free muscle transplantation are some of the therapeutic options for secondary reconstructive procedures that can be performed at any time.

\section{Arthrodesis}

In traumatic injuries of the complete brachial plexus, the arthrodesis that results in shoulder stabilization allows the orthopedic to collect all potential nerve grafts to continue the procedure. On the other hand, in upper BPI with a somewhat unstable and painful shoulder, arthrodesis may be a definite solution. When planning shoulder arthrodesis, certain parameters must be taken into account. First, good thoracicshoulder functionality is essential. Second, peripheral hand motion mobility is important because shoulder arthrodesis does not have any clinical effect on paralytic hands. The acromioclavicular, sternoclavicular, and scapula-thoracic joints must be intact. Any dysfunction can affect the success of the arthrodesis [1], [2].

The shoulder should be fused with $20^{\circ}$ of abduction, $30^{\circ}$ of flexion, and $20^{\circ}$ of internal rotation to allow the patient to be independent in daily life with an average range of $60^{\circ}$ of abduction and flexion through the scapulothoracic joint [1], [2], [17].

\section{Transfer of tendon}

Tendon transfers are useful in restoring upper limb function following brachial plexus injury. The absolute indication is traumatic upper or lower brachial plexus injury with only partial paralysis. Muscle strength cannot return to pre-injury levels after tendon transfer.

Many tendon transfer techniques have been described. A decision should be taken only when all options have been assessed. The most common procedures are as follows [1], [2], [17], [69]:

a. Transfer of trapezius to deltoid (Elhassan et al.) to correct shoulder abduction;

b. Transfer of the latissimus dorsi (L 'Episcopo), to enhance external rotation. The technique can be used at the same time as removing part of the anterior joint capsule and releasing the subscapular and pectoralis major muscles or even with an external rotational osteotomy of the humerus;

c. Anterior transfer of the posterior branch of the deltoid muscle to restore the non-functioning anterior segment;

d. Modified flexorplasty

e. Jones' transfer 


\section{Free functional muscle transfer (FFMT)}

FFMT is transfer of muscle using microvascular anastomosis for revascularization and subsequent microneural coaptation to recipient motor nerves for reinnervation.

Changes that result from muscle denervation can be biochemical and/or morphological. The disorganization is complete after 2 years of denervation and the muscle is finally replaced by fat tissue. Within 2-3 months after the posttraumatic period, denervated muscle fibers lose $50 \%$ of their diameter due to atrophy. In many cases, surgical delay or complete avulsion of the brachial plexus limits the ability to achieve good results. The functional results of various shoulder and elbow movements with the use of nerve transfer and nerve grafting techniques, and functional recovery of the hand are often disappointing.

For this reason, FFMT should be considered in older cases more than 9-12 months. Restoration of elbow flexion and wrist extension function in brachial plexus paralysis and even complete brachial plexus avulsion can be successful by implementing FFMT technique for reinnervation [2], [45] (Table 5).

\section{Prognosis}

The results of the intervention varied depending on several parameters [8], [9], [40], [41], [43], [44], [60], [67]:

- $\quad$ High-energy trauma and avulsion trauma will give a poor prognosis than acute rupture.

- $\quad$ Better prognosis in younger patients.

- Functional healing is much better than that which occurs with sensory or motor damage alone if sensory and motor nerves are transferred.

- Prognosis of supraclavicles involvement is worse than that of infraclavicular lesions; upper brachial plexus type injury has a better prognosis.

\section{$\bullet$}

Patients who experienced pain treatment for more than 6 months after trauma often has a lower rate of healing.

- Fibrosis and degeneration of organ marks during surgery are associated with a poor prognosis

- $\quad$ The presence of secondary infection gives a poor prognosis.

- $\quad$ Patients undergoing rehabilitation programs can improve their functional abilities better.

\section{Future Management}

\section{The use of stem cell}

Is an augmentative treatment to provide a conducive environment for axon regeneration. The number of Schwann cells that play a role in the peripheral nerves regeneration will increase by administering mesenchymal stem cells. These exogenous stem cells will differentiate into phenotypes such as Schwann cells which integrate into the Band of Bungner and become axonal guides in regeneration and remyelination processes. The production of several growth factors during peripheral nerve trans-axotomy which important in the regeneration process will increase by administering these exogenous stem cells through their secretions (paracrine function). Several growth factors that are important in the process of nerve regeneration include NGF, BDNF, GDNF, CNTF, NT-3, VEGF, bFGF, HGF, and angiopontin-1 [36], [70].

\section{Brachial plexus reimplantation - role of neurotrophic factors}

Motor neuron cellular death from the anterior spinal cord occurred 6 weeks after complete avulsion of the brachial plexus and only $40 \%$ of these remained. Direct reimplantation or use of peripheral nerve

Table 5: Clinical features, surgical options, and outcomes

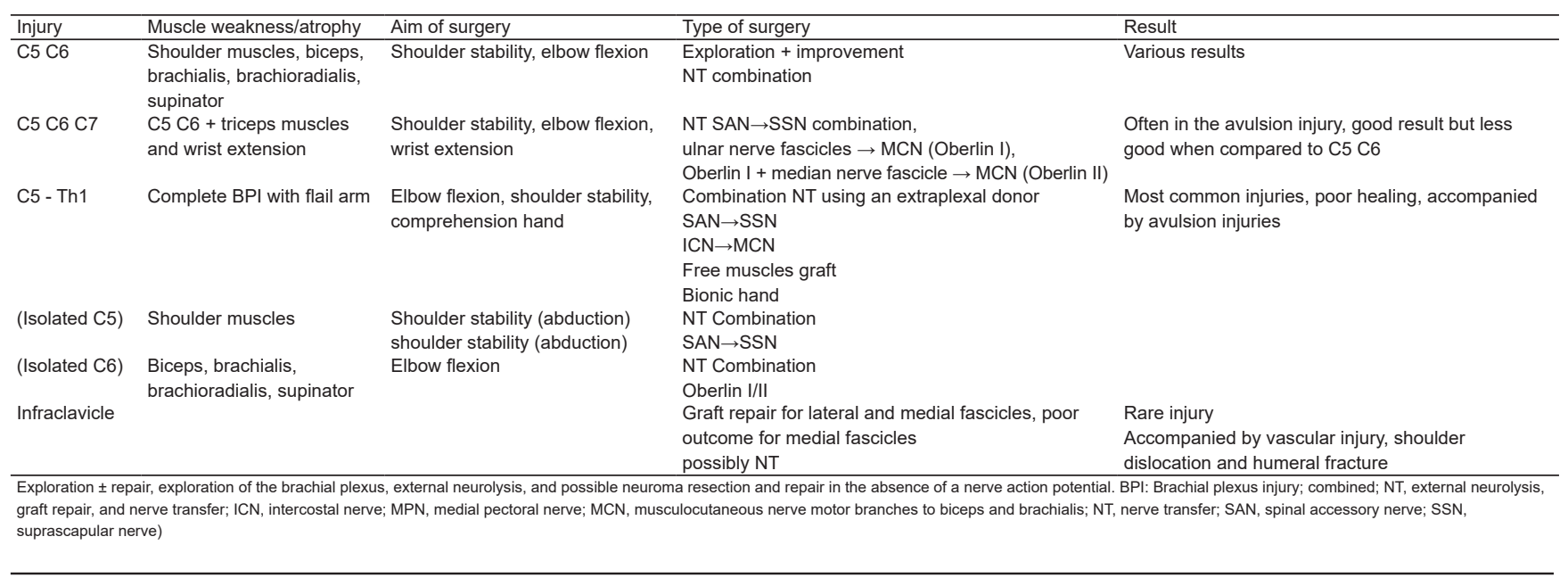


autografts can increase the total number of motor neurons remaining by up to $80 \%$ after 6 weeks. This procedure is associated with spinal axon regeneration and functional recovery. Schwann cells are the main glial cells responsible for regeneration. Research has shown that Schwann cells will become active after peripheral axon dissection and continue to release neurotrophic factors and produce extracellular matrix [1], [2].

\section{The use of bionic hands}

Hand reconstruction will see many new approaches to replace a missing or non-functioning limb. The bionic hand using a myoelectric approach. Myoelectric prostheses use the electrical voltage generated each time a muscle contracts to control some movement. In patients with brachial plexus injury, this type of prosthesis uses the rest of the human body's neuromuscular system to control flexion/extension of the elbow, supination/pronation of the forearm (rotation), or flexion/extension of the fingers (hand resistance function) [70], [71].

\section{Conclusion}

The management of brachial plexus injuries requires careful planning for primary and secondary reconstruction. This injury is difficult for the patient and his family to accept, so a thorough treatment is needed. Patients and their families must be well informed that no guarantee of promising results with the procedure. Providing optimal therapy, clinicians must understand the overall anatomy, clinical assessment, radiological examination, and electrodiagnostic study so that the choice of method and timing of therapy is appropriate. In severe panplexal injuries, selecting the appropriate method of therapy allows the patient to be able to use the upper limb such as elbow flexion, shoulder abduction even if it is limited. Although the hand function is limited, it is still useful for daily functions. Recognizing the basic principles of management of brachial plexus injuries is essential.

\section{Author Contributions}

Tito Sumarwoto, Heri Suroto, Ferdiansyah Mahyudin, Dwikora Novembri Utomo, Pamudji Utomo, Romaniyanto, R. Andhi Prijosedjati, Seti Aji Hadinoto, Sholahuddin Rhatomy, and Muhammad Abdulhamid collected and examined the articles, and wrote the review article, with about equal contribution

\section{Acknowledgment}

We thank the staff of Klinik Bahasa for their help during manuscript preparation.

\section{References}

1. Sakellariou VI, Badilas NK, Stavropoulos NA, Mazis G, Kotoulas HK, Kyriakopoulos S, et al. Treatment options for brachial plexus injuries. ISRN Orthop. 2014;2014:314137. https://doi.org/10.1155/2014/314137

PMid:24967125

2. Thatte MR, Babhulkar S, Hiremath A. Brachial plexus injury in adults: Diagnosis and surgical treatment strategies. Ann Indian Acad Neurol. 2013;16(1):26-33. https://doi. org/10.4103/0972-2327.107686

PMid:23661959

3. Alolabi N, Lovy AJ, Kircher MF, Spinner RJ, Bishop AT, Shin AY Distal nerve transfers to the triceps brachii muscle: Surgical technique and clinical outcomes. J Hand Surg. 2020;45(2):155. e1-8. https://doi.org/10.1016/j.jhsa.2019.05.005 PMid:31221517

4. Alrabai HM, Gesheff MG, Hammouda AI, Conway JD. Trapezius muscle transfer for restoration of elbow extension in a traumatic brachial plexus injury. J Hand Surg. 2018;43(9):872.e1-6. https://doi.org/10.1016/j.jhsa.2018.02.005 PMid:29650376

5. Augustine HF, Coroneos CJ, Choi M, Bain JR. Adjunctive dorsa scapular nerve transfer to suprascapular nerve for brachial plexus birth injuries: Case series. J Hand Surg Am. 2019;44(10):902. e1-9. https://doi.org/10.1016/j.jhsa.2018.12.008 PMid:30737063

6. Bertelli JA, Ghizoni MF. Reconstruction of complete palsies of the adult brachial plexus by root grafting using long grafts and nerve transfers to target nerves J Hand Surg Am. 2010;35(10):1640-6. https://doi.org/10.1016/j.jhsa.2010.06.019

PMid:20843615

7. Bauer AS, Rabinovich RV, Waters PM. The anterior approach for transfer of radial nerve triceps fascicles to the axillary nerve. J Hand Surg Am. 2019;44(4):345.e1-6. https://doi.org/10.1016/j. jhsa.2018.10.019

PMid:30502016

8. Bhandari PS, Deb P. Posterior approach for both spinal accessory nerve to suprascapular nerve and triceps branch to axillary nerve for upper plexus injuries. J Hand Surg Am. 2013;38(1):168-72. https://doi.org/10.1016/j.jhsa.2012.10.024 PMid:23261196

9. Carlsen BT, Kircher MF, Spinner RJ, Bishop AT, Shin AY Comparison of single versus double nerve transfers for elbow flexion after brachial plexus injury. Plast Reconstr Surg. 2011;127(1):269-76. https://doi.org/10.1097/ prs.0b013e3181f95be7 PMid:20871484

10. Chim H, Kircher MF, Spinner RJ, Bishop AT, Shin AY. Free functioning gracilis transfer for traumatic brachial plexus injuries in children. J Hand Surg Am. 2014;39(10):1959-66. https://doi. org/10.1016/j.jhsa.2014.06.020

PMid:25064624

11. Chuang DC, Hernon C. Minimum 4-year follow-up on 
contralateral C7 nerve transfers for brachial plexus injuries. J Hand Surg Am. 2012;37(2):270-6. https://doi.org/10.1016/j. jhsa.2011.10.014

PMid:22173004

12. Kodama N, Doi K, Hattori $\mathrm{Y}$. Force recovery assessment of functioning free muscle transfers using ultrasonography. J Hand Surg Am. 2014;39(11):2269-76. https://doi.org/10.1016/j. jhsa.2014.06.120

PMid:25085046

13. Kosiyatrakul A, Jitprapaikulsarn S, Durand S, Oberlin C. Recovery of brachial plexus injury after shoulder dislocation. Injury. 2009;40(12):1327-9. https://doi.org/10.1016/j. injury.2009.05.015

PMid:19540487

14. Lam WL, Fufa D, Chang NJ, Chuang DC. Management of infraclavicular (Chuang Level IV) brachial plexus injuries: A single surgeon experience with 75 cases. J Hand Surg Eur Vol. 2015;40(6):573-82. https://doi.org/10.1177/1753193414553753 PMid:25294737

15. Landers ZA, Jethanandani R, Lee SK, Mancuso CA, Seehaus M, Wolfe SW. The psychological impact of adult traumatic brachial plexus injury. J Hand Surg Am. 2018;43(10):950.e1-6. https:// doi.org/10.1016/j.jhsa.2018.02.019

PMid:29678427

16. Malungpaishrope $\mathrm{K}$, Leechavengvongs $\mathrm{S}$, Witoonchart $\mathrm{K}$, Uerpairojkit C, Boonyalapa A, Janesaksrisakul D. Simultaneous intercostal nerve transfers to deltoid and triceps muscle through the posterior approach. J Hand Surg Am. 2012;37(4):677-82. https://doi.org/10.1016/j.jhsa.2011.12.034 PMid:22381948

17. Spinner RJ, Shin AY, Elhassan BT, Bishop AT. Traumatic brachial plexus injury. In: Wolfe SW, Hotchkiss RN, Pederson WC, Kozin SH, Cohen MS, editors. Green's Operative Hand Surgery. $7^{\text {th }}$ ed., Vol. 7. Philadelphia, PA, United States: Elsevier; 2017. p. 1146-207. https://doi.org/10.1016/b978-1-4160-5279-1.00038-1

18. Middleton AH, Roffers J, Ziegler DW. Complete brachial plexus palsy following shoulder dislocation due to sneeze: A case report. Int J Emerg Med. 2019;12(1):28. https://doi.org/10.1186/ s12245-019-0245-8 PMid:31519168

19. Elzinga KE, Curran MW, Morhart MJ, Chan KM, Olson JL. Open anterior release of the superior transverse scapular ligament for decompression of the suprascapular nerve during brachial plexus surgery. J Hand Surg Am. 2016;41(7):e211-5. https://doi. org/10.1016/j.jhsa.2016.03.005

PMid:27113908

20. Gadinsky NE, Smolev ET, Ricci MJ, Mintz DN, Wellman DS. Two cases of brachial plexus compression secondary to displaced clavicle fractures. Trauma Case Rep. 2019;23:100219. https:// doi.org/10.1016/j.tcr.2019.100219

PMid:31467966

21. Goubier JN, Teboul F, Khalifa H. Reanimation of elbow extension with intercostal nerves transfers in total brachial plexus palsies. Microsurgery. 2010;31(1):7-11. https://doi.org/10.1002/ micr.20822

PMid:21207492

22. Grossman JA, Price A, Chim H. Complications in surgery for brachial plexus birth injury: Avoidance and treatment. $J$ Hand Surg Am. 2018;43(2):164-72. https://doi.org/10.1016/j. jhsa.2017.11.008 PMid:29421066

23. Gutkowska O, Martynkiewicz J, Stępniewski M, Gosk J. Analysis of patient-dependent and trauma-dependent risk factors for persistent brachial plexus injury after shoulder dislocation. Biomed Res Int. 2018;2018:4512137. https://doi. org/10.1155/2018/4512137

PMid:29546059

24. Gutkowska O, Martynkiewicz J, Mizia S, Bąk M, Gosk J. Results of operative treatment of brachial plexus injury resulting from shoulder dislocation: A study with a long-term follow-up. World Neurosurg. 2017;105:623-31. https://doi.org/10.1016/j. wneu.2017.06.059

PMid:28624567

25. Hems TE, Mahmood F. Injuries of the terminal branches of the infraclavicular brachial plexus: Patterns of injury, management and outcome. J Bone Joint Surg Br. 2012;94(6):799-804. https:// doi.org/10.1302/0301-620x.94b6.28286 PMid:22628595

26. Ho ES, Davidge K, Curtis CG, Clarke HM. Sensory outcome in children following microsurgery for brachial plexus birth injury. $J$ Hand Surg Am. 2019;44(2):159.e1-8. https://doi.org/10.1016/j. jhsa.2018.05.009

PMid:30042027

27. Impastato DM, Impastato KA, Dabestani P, Ko JH, Bunnell AE. Prognostic value of needle electromyography in traumatic brachial plexus injury. Muscle Nerve. 2019;60(5):595-7. https:// doi.org/10.1002/mus.26684

PMid:31452215

28. Kaiser R, Haninec P. The influence of seatbelts on the types of operated brachial plexus lesions caused by car accidents. J Hand Surg Am. 2012;37(8):1657-9. https://doi.org/10.1016/j. jhsa.2012.05.019

PMid:22763056

29. Moran SL, Steinmann SP, Shin AY. Adult brachial plexus injuries: Mechanism, patterns of injury, and physical diagnosis. Hand Clin. 2005;21(1):13-24. https://doi.org/10.1016/j.hcl.2004.09.004 PMid: 15668062

30. Daly MC, Bauer AS, Lynch H, Bae DS, Waters PM. Outcomes of late microsurgical nerve reconstruction for brachial plexus birth injury. J Hand Surg Am. 202045(6):555.e1-9. https://doi. org/10.1016/j.jhsa.2019.10.036

PMid:31928798

31. Johnson GJ, Denning S, Clark SL, Davidson C. Pathophysiologic origins of brachial plexus injury. Obstet Gynecol. 2020;136(4):72530. https://doi.org/10.1097/aog.0000000000004013 PMid:32925630

32. Raducha JE, Cohen B, Blood T, Katarincic J. A review of brachial plexus birth palsy: Injury and rehabilitation. R I Med J (2013). 2017;100(11):17-21. PMid:29088569

33. Kaya Y, Sarikcioglu L. Sir Herbert Seddon (1903-1977) and his classification scheme for peripheral nerve injury. Childs Nerv Syst. 2015;31(2):177-80. https://doi.org/10.1007/ s00381-014-2560-y PMid:25269543

34. Waldram M. Peripheral nerve injuries. Trauma. 2003;5(2):79-96.

35. Campbell WW. Evaluation and management of peripheral nerve injury. Clin Neurophysiol. 2008;119(9):1951-65. PMid: 18482862

36. Grinsell D, Keating CP. Peripheral nerve reconstruction after injury:Areview of clinical and experimental therapies. Biomed Res Int. 2014;2014:698256. https://doi.org/10.1155/2014/698256 PMid:25276813

37. Sunderland SS. The anatomy and physiology of nerve injury. Muscle Nerve. 1990;13(9):771-84. https://doi.org/10.1002/ mus. 880130903

PMid:2233864

38. Yang J, Qin B, Fu G, Li P, Zhu Q, Liu X, et al. Modified pathological 
classification of brachial plexus root injury and its MR imaging characteristics. J Reconstr Microsurg. 2014;30(3):171-8. https:// doi.org/10.1055/s-0033-1357498

\section{PMid:24163228}

39. Flores LP. The importance of the preoperative clinical parameters and the intraoperative electrophysiological monitoring in brachial plexus surgery. Arq Neuropsiquiatr. 2011;69(4):654-9. https://doi.org/10.1590/s0004-282x2011000500015 PMid:21877036

40. Shafi M, Hattori $Y$, Doi K. Surgical technique of harvesting vascularized superficial radial nerve graft. J Hand Surg Am. 2010;35(2):312-5. https://doi.org/10.1016/j.jhsa.2009.11.018 PMid:20141903

41. Smania N, Berto G, La Marchina E, Melotti C, Midiri A, Roncari L, et al. Rehabilitation of brachial plexus injuries in adults and children. Eur J Phys Rehabil Med. 2012;48(3):483-506. PMid:23075907

42. O'Shea K, Feinberg JH, Wolfe SW. Imaging and electrodiagnostic work-up of acute adult brachial plexus injuries. J Hand Surg Eur Vol. 2011;36(9):747-59. https://doi. org/10.1177/1753193411422313

PMid:21921067

43. Russo SA, Killelea CM, Zlotolow DA, Kozin SH, Rodriguez LM, Chafetz RS, et al. Scapular stabilization limits glenohumeral stretching in children with brachial plexus injuries. J Hand Surg Am. 2019;44(1):63.e1-9. https://doi.org/10.1016/j. jhsa.2018.04.025 PMid:29934088

44. Sarac C, Hogendoorn S, Nelissen RG. A new surgical technique for internal shoulder contractures secondary to obstetric brachial plexus injury: An anterior coracohumeral ligament release. J Brachial Plex Peripher Nerve Inj. 2019;14(1):E35-8. https://doi. org/10.1055/s-0039-1693746

PMid:31413723

45. Sakellariou VI, Badilas NK, Mazis GA, Stavropoulos NA, Kotoulas HK, Kyriakopoulos $\mathrm{S}$, et al. Brachial plexus injuries in adults: Evaluation and diagnostic approach. ISRN Orthop. 2014;2014:726103. https://doi.org/10.1155/2014/314137 PMid:24967130

46. Nagano Y, Kawamura D, Terkawi A, Urita A, Matsui Y, Iwasaki N. Minimum ten-year outcomes of partial ulnar nerve transfer for restoration of elbow flexion in patients with upper brachial plexus injury. J Hand Surg Asian Pac Vol. 2019;24(3):283-8. https://doi.org/10.1142/s2424835519500358

PMid:31438804

47. Ramalho BL, Rangel ML, Schmaedeke AC, Erthal FS, Vargas $C D$. Unilateral brachial plexus lesion impairs bilateral touch threshold. Front Neurol. 2019;10:872. https://doi. org/10.3389/fneur.2019.00872

PMid:31456738

48. Neal SL, Fields KB. Peripheral nerve entrapment and injury in the upper extremity. Am Fam Physician. 2010;81(2):147-55. PMid:20082510

49. Noland SS, Bishop AT, Spinner RJ, Shin AY. Adult traumatic brachial plexus injuries. J Am Acad Orthop Surg. 2019;27(19):705-16. PMid:30707114

50. Rhee PC, Pirola E, Hébert-Blouin MN, Kircher MF, Spinner RJ, Bishop AT, et al. Concomitant traumatic spinal cord and brachial plexus injuries in adult patients. J Bone Joint Surg Am. 2011;93(24):2271-7. https://doi.org/10.2106/jbjs.j.00922 PMid:22258773

51. Terzis JK, Vekris MD, Soucacos PN. Outcomes of brachial plexus reconstruction in 204 patients with devastating paralysis.
Plast Reconstr Surg. 1999;104(5):1221-40. https://doi. org/10.1097/00006534-199910000-00001

PMid:10513901

52. Kokatnur L, Rudrappa M. Diaphragmatic palsy. Diseases. 2018;6(1):16.

PMid:29438332

53. Doi K, Otsuka K, Okamoto Y, Fujii H, Hattori Y, Baliarsing AS. Cervical nerve root avulsion in brachial plexus injuries: Magnetic resonance imaging classification and comparison with myelography and computerized tomography myelography. J Neurosurg. 2002;96 Suppl 3:277-84. https://doi.org/10.3171/spi.2002.96.3.0277 PMid:11990835

54. Fuzari HK, de Andrade AD, Vilar CF, Sayão LB, Diniz PR, Souza $\mathrm{FH}$, et al. Diagnostic accuracy of magnetic resonance imaging in post-traumatic brachial plexus injuries: A systematic review. Clin Neurol Neurosurg. 2018;164:5-10. https://doi. org/10.1016/j.clineuro.2017.11.003 PMid:29145043

55. Yoshikawa T, Hayashi N, Yamamoto S, Tajiri Y, Yoshioka N, Masumoto T, et al. Brachial plexus injury: Clinical manifestations, conventional imaging findings, and the latest imaging techniques. Radiographics. 2006;26 Suppl 1:S133-43. https:// doi.org/10.1148/rg.26si065511

PMid:17050511

56. Chin B, Ramji M, Farrokhyar F, Bain JR. Efficient imaging: Examining the value of ultrasound in the diagnosis of traumatic adult brachial plexus injuries, a systematic review. Neurosurgery. 2018;83(3):323-32. https://doi.org/10.1093/neuros/nyx483 PMid:29040777

57. Mazal AT, Faramarzalian A, Samet JD, Gill K, Cheng J, Chhabra A. MR neurography of the brachial plexus in adult and pediatric age groups: Evolution, recent advances, and future directions. Expert Rev Med Devices. 2020;17(2):111-22. https:// doi.org/10.1080/17434440.2020.1719830 PMid:31964194

58. Mansukhani KA. Electrodiagnosis in traumatic brachial plexus injury. Ann Indian Acad Neurol. 2013;16(1):19-25. https://doi. org/10.4103/0972-2327.107682 PMid:23661958

59. Ferrante MA. Electrodiagnostic assessment of the brachial plexus. Neurol Clin. 2012;30(2):551-80.

PMid:22361374

60. Rich JA, Newell A, Williams T. Traumatic brachial plexus injury rehabilitation using neuromuscular electrical muscle stimulation in a polytrauma patient. BMJ Case Rep. 2019;12(12):e232107. https://doi.org/10.1136/bcr-2019-232107 PMid:31874847

61. Dy CJ, Peacock K, Olsen MA, Ray WZ, Brogan DM. Frequency and risk factors for prolonged opioid prescriptions after surgery for brachial plexus injury. J Hand Surg Am. 2019;44(8):662-8. e1. https://doi.org/10.1016/j.jhsa.2019.04.001 PMid:31078338

62. Monreal R, Gómez D, Osinaga G, Monreal E. Surgical options for brachial plexus injury in adults. Orthop Rheumatol. 2017;6(3):1-5.

63. Tu Y, Kakinoki R, Leechavengvongs S, Shin AY, Tan JS. Current trends in management of adult brachial plexus palsy Part I: Upper arm type. In: IFSSH Scientific Committee on Brachial Plexus Injury; 2015. p. 1-30.

64. Coulet B, Boretto JG, Lazerges C, Chammas M. A comparison of intercostal and partial ulnar nerve transfers in restoring elbow flexion following upper brachial plexus injury (C5-C6+/-C7). J Hand Surg Am. 2010;35(8):1297-303. https://doi.org/10.1016/j. jhsa.2010.04.025

PMid:20638201 
65. Srinivasan RC, Pederson WC, Morrey BF. Distal biceps tendon repair and reconstruction. J Hand Surg Am. 2020;45(1):48-56. https://doi.org/10.1016/j.jhsa.2019.09.014

PMid:31901332

66. Zlotolow DA, Low SL, Lin IC, Williamson C, Tinsley B, Kozin SH. Suprascapular ligament release from an anterior approach: An anatomic feasibility study. J Hand Surg Am. 2019;44(10):900. e1-4. https://doi.org/10.1016/j.jhsa.2018.12.005 PMid:30733096

67. Soldado F, Ghizoni MF, Bertelli J. Injury mechanisms in supraclavicular stretch injuries of the brachial plexus. Hand Surg Rehabil. 2016;35(1):51-4. https://doi.org/10.1016/j. hansur.2015.09.001

PMid:27117025

68. Song J, Qiu WJ, Chen L, Hu SN, Wu JX, Gu YD. Transfers of the ipsilateral $\mathrm{C} 7$ plus the spinal accessory nerve versus triple nerve transfers for treatment of $\mathrm{C} 5-\mathrm{C} 6$ avulsion of the brachial plexus.
J Hand Surg Am. 2020;45(4):363.e1-6. https://doi.org/10.1016/j. jhsa.2019.09.010

PMid:31718845

69. Elhassan BT, Wagner ER, Spinner RJ, Bishop AT, Shin AY Contralateral trapezius transfer to restore shoulder external rotation following adult brachial plexus injury. J Hand Surg Am. 2016;41(4):e45-51. https://doi.org/10.1016/j.jhsa.2015.12.026 PMid:26787407

70. Suroto H. Masa depan penanganan lesi pleksus brakialis. In: Mahyudin F, editor. Lesi Pleksus Brakialis Tata Laksana Komprehensif. $1^{\text {st }}$ ed. Surabaya, Indonesia: Pusat Penerbitan dan Percetakan Universitas Airlangga; 2019. p. 1-142.

71. Carey SL, Lura DJ, Highsmith MJ, CP, FAAOP. Differences in myoelectric and body-powered upper-limb prostheses: Systematic literature review. J Rehabil Res Dev. 2015;52(3):24762. https://doi.org/10.1682/jrrd.2014.08.0192

PMid:26230500 